\title{
Digital Native Pre-Service Teachers' Perceptions of using Commercial and Open Source Online Applications in Future Praxis after Completing Technology Integration Course
}

\author{
Mehmet Ali Ozer \\ New Mexico State Univerity \\ Las Cruces, NM, US \\ Joann Latorre, David Rutledge, Tahani Mansour and Armando Altamirano
}

\begin{abstract}
Exposure to new technologies is commonplace for most people lived in the 21st century. As technology evolves, so does a generation of learners whose identity is shaped by how they manage these technological tools. The participants of this study were digital native preservice teachers (DNPST) who were exposed to technology since childhood and enrolled in a technology integration course at a border city university. This study investigates DNPST's perceptions upon exposure to alternate models of technology tools and their intentions for implementing them into their future classroom repertoire. The method of data collection for this quantitative study consisted of pre and post-test surveys. Data analysis was completed using the Wilcoxon Rank Sum-Test. Results of this study indicated that the technology methods course did not have a significant effect on pre-service teachers' perceptions to adopt technology tools for future classroom instruction. This study was encouraged by the department of education and the results obtained through this study will allow curricular updates.
\end{abstract}

Keywords: Teacher education; educational technologies; higher education; teacher preparation programs.

\section{Introduction and Background}

Teacher education professionals working with digital native pre-service teachers (DNPST) strive to find ways to connect the university learning environment to pre-service teachers' future teaching careers. Recognizing that DNPST are often assumed to be proficient at using technology does not always correlate with the actual abilities they bring to their development as teacher candidates. In an attempt to make sense of this potential disconnect this study 
investigates how DNPST perceive freely accessible online technologies as tools for improving their competency, attitude, learning and teaching.

This study focuses on DNPST enrolled in a teacher technology integration course at South Mountain University (SMU), Educational Learning Design and Technologies 321 (ELDT 321): Integrating Technology with Teaching course. ELDT 321 is a prerequisite course for SMU's teacher preparation program. In a previous study Rutledge, Ozer, Altamirano, Mansour, and Latorre (2016) suggested that DNPSTs' high level of self-perceived computer competency does not imply that they have a strong position towards using free versions of Commercial and Open Source Online Applications (COSOA) in the classroom.

\section{Significance of the Study}

Technology can be a motivational enterprise in classrooms. Dwyer (1996), Golberg, Russell, \& Cook (2003) and Marri (2005) discuss the importance of technology as a tool that improves the mastery of teaching and communication skills; a helper for students to achieve better learning while being engaged. The New Media Consortium (NMC) is an international not-forprofit consortium consisting of more than 250 corporations and universities devoted to the exploration and use of new technologies in higher education. Included in the NMC 2017 Horizon Report, (Adams, Cummins, Davis, Freeman, Hall, Ananthanarayanan, 2017) is the importance of educating the future labor force by using the internet. The report explains how the development of the internet has brought new exciting and powerful online tools that are free to use and readily available online. According to the report, people can more than ever access limitless amounts of global data, and furthermore, free online teaching technologies are being developed by different organizations and corporations for everyone to use.

In order to strive for $21^{\text {st }}$ century learning, DNPST' classes must focus on the successful integration of new technologies and COSOAs in their classrooms. This study plays an important role in enhancing our understanding of how preservice teachers perceive COSOAs for teaching. The pedagogical and curricular implications on how to successfully apply technology in classrooms are explained and demonstrated in ELDT 321. The learning outcome for this class is to provide pre-service teachers with methods and ideas for incorporating COSOAs within their lesson plan template. The current literature focuses on primarily on how DNPST use these tools in school. However, there is a gap in research on how DNPST perception change after exploring these tools in classroom. This study is uncovering how teacher candidates think about using these tools that they explored in technology integration course in their future classrooms. 


\section{Theoretical Framework}

In classrooms it is very common to see one teacher using various kinds of student-oriented strategies which involves different technology tools in a school, while another teacher, across the hallway, still uses the older teacher-oriented strategies. Teachers get technology integration education during their preservice teacher preparation programs before getting into classroom and actual teaching, and while working as teachers they receive in-service training on technology usage throughout their career. However, every single teacher's gain from these educational sessions differ from others. Teachers technology usage can be affected by the knowledge they have about using technology as well as some other factors. Ajzen and Fishbein (1980) state that these factors can be directly related to perceived usefulness and perceived ease of use. Perceived usefulness means the degree which a user believes that using a technology tool will improve their performance and perceived ease of use refers to the degree which a user believes that using a technology tool will be almost free from effort (Lim, 2018). Venkatesh and Davis (2000) suggest that along with perceived usefulness and ease of use, experience and voluntariness play an important role for attitude towards using technology and behavioral intention to use.

\section{Literature review}

\section{Digital Natives}

The concept of digital natives has emerged from divergent perspectives. The discussion began more than a decade ago when academics such as Tapscott (2009), Howe and Strauss (2000) and Prensky (2001), introduced the phenomena to the world of academia and education. These scholars initially used a variety of terms such as net generation, millennials and digital natives accordingly. Digital natives simply describe the people who were born in the digital age (Prensky, 2009) after the year 1980 ("Homo Zappiens", 2017). It was predicted that this new generation would benefit from different types of educational approaches or even educational reforms due to the expansive nature of technology (Prensky, 2009). For example, Lambert and Cuper (2008) state that pre-service teachers need to become familiar with the multimedia tools which are highly used by students. Furthermore, Tapscott (2009) states that development of new educational approaches is inevitable in the 21st century because our lives and life expectations of our students has changed dramatically.

On the other hand, recent critiques target even the existence of "digital natives". Kirschner and De Bruyckere (2017) define the phenomena as

"yeti-like creatures populating present day schools namely digital natives and human multitaskers" (p. 135). 
Kirschner and De Bruyckere (2017) think that all the efforts done to meet the needs of digital native students is

"a non-solution for a non-existing problem." Kirschner and De Bruyckere (2017) state "In designing the learning environment, teachers and teacher trainers should be wary of arguments for pedagogical change based on the non-existing digital natives" (p. 140).

According to Margaryan, Littlejohn and Vojt (2011), digital natives use technology mostly for non-educational or non-socialization purposes; in their opinion, there is no need for any educational reforms or developments to meet so called digital natives needs.

According to literature even technology companies had a great impact on the process of development of the digital natives phenomena. These companies sometimes played critical roles through the way. Bullen and Morgan (2016) argue that the digital native phenomena emerged from non-scholarly literature and some of the studies suggesting these educational reforms are funded by and conducted for private tech companies. This situation inhibited an objective evaluation of the phenomena at the time of its emergence.

\section{Digital Natives and COSOA}

Digital native pre-service teachers' exposure to technology is commonplace. This study investigates the adoption of technology practices of pre-service teachers who are enrolled in a technology integration course. This study also explores pre-service teachers' management with current technology tools and their willingness to expand their technology repertoire for teaching purposes. Vast majority of the students attending this class can be considered "digital natives" (Prensky, 2009) as they have grown up surrounded by technology, experienced its use since birth and were born after 1980 .

Digital natives spend most of their time online,

"busy adopting new systems for communicating (instant messaging), sharing (blogs), buying and selling (eBay), exchanging (peer-to-peer technology), creating (Flash), meeting (3D worlds), collecting (downloads), coordinating (wikis), evaluating (reputation systems), searching (Google), analyzing (SETI), reporting (camera phones), programming (modding), socializing (chat rooms), and even learning (Web surfing)" (Prensky, 2005, p. 9).

According to Levin and Arafeh (2002), the benefit of being a digital native is evident in being capable of using different technologies effortlessly and in adapting to technology changes faster than older generations. Another benefit for digital natives is their ability to feel comfortable when interacting with new technologies and not being afraid of using them (Prensky, 2001). These technological competencies make DNPST perfect candidates for integrating emerging technologies in their classrooms (National Council for Accreditation of 
Teacher Education, 2007; International Society for Technology in Education, 2008).

According to Drumea (2012), the relentless evolution of software has brought to the market free Open Source Applications (OSAs) as a solution to costly, disconnected, and complex commercial applications. The Commercial and Open Source Applications (COSOA) taught in ELDT-321 are based on OSAs and web-based, free, limited versions of commercial software. The limited versions are restricted in the extent of program features such as, storage space provided, program time limit, number of fonts and colors available, quality of graphics, etc. Program restrictions are not crippling for beginning users, and these software serve DNPST' purpose well in class. ELDT 321 focuses on teaching Web 2.0 applications that develop student competencies for crafting online content. Greenhow, Robelia and Hughes (2009) discuss how Web 2.0 tools have helped regular people develop digital competencies that allow them to create new content, share data and join groups in the online world.

It is important that DNPST understand how the technologies they have been exposed to since childhood can be used to teach. Zhao, Pugh, Sheldon, and Byers (2002) add that the implementation of new technologies into teaching is a messy process. DNPST' technology competency and beliefs about how technology tools are effective in education and it is crucial for DNPST to use these tools in classroom (Bai \& Ertmer, 2008). Research have shown that DNPST' attitudes toward self-competency and their personal beliefs about technology directly affect the pedagogic intention and likelihood of implementing new technologies in their classrooms (Tondeur, van Braak, Ertmer, \& OttenbreitLeftwich, 2017; Anderson \& Maninger, 2007; Teo, Lee, Chai, \& Wong, 2009; Choy, Wong, \& Gao, 2009). On the other hand, the importance of pre-service and in-service teacher preparation has a great effect on DNPST' will to use technology in classroom. Systematic professional growth throughout teaching career is key for today's classroom. Tondeur et al. (2017) state that professional development is key to technology integration. According to Mouza and Karchmer-Klein (2013) there is a great need for professional development in learning to teach with technology for educators. Also, Corkett and Benevides (2015) and Teo (2009) support the idea of introducing different types of technology tools that DNPST may encounter or need in classrooms through preservice teacher education or professional development sessions.

\section{Teacher Education and Teacher Technology Competencies}

Teacher technology competency relates to teachers' computer and COSOA competency, and includes the ability to locate, use, and integrate COSOA into teaching by harnessing the features and affordances (AsingCashman, Gurung, Limbu, and Rutledge, 2014). Technology competency for preservice teachers plays a significant role for integrating technology into their future teaching praxis. Baylor and Ritchie (2002) state that,

"...to effectively broaden the range of instructional opportunities that can be offered to students, teachers must reach and maintain a certain degree of technological competence" (p. 8) because using technology 
"...does not directly change teaching or learning. Rather, the critical element is how technology is incorporated into instruction" (Office of Technology Assessment, 1995, p. 57).

Teachers need to be taught about how to integrate technology tools into education rather than teaching what these technology tools are to teachers or teacher candidates. However, teachers cannot be taught on how to integrate technology into teaching if they do not know about these technology tools. According to Uerz, Volman, and Kral (2018) teachers need to be furnished with the latest technologies because they bare responsibility for preparing technologically literate citizens in a twenty-first-century society where technological developments are constantly in flux. As a result, understanding and developing preservice teachers' competency in technology use is the cornerstone in integrating technology into teaching.

The preparation for educational technology competency usually begins during teacher education programs. Baylor and Ritchie (2002) explain that deficiencies of teacher preparation programs affect pre-service teachers' knowledge competency. Therefore, courses such as ELDT 321 are paramount in transforming teaching and learning with a focus in technology integration. Further examination of teacher preparation programs provides this study with a background to understand the role of technology and COSOA competencies on attitudes toward COSOA and the intention to use COSOA.

Our investigation supports Asing-Cashman, Gurung, Limbu, and Rutledge (2014) who examined COSOA use through an empirical study of preservice teachers' competencies, attitudes, and pedagogical intentions. Results obtained from this study serve as an analysis for comparison to the original study as a reflection of the course materials and curriculum planning. Our goal in this current study is to provide augmentation for such course objectives and learning outcomes for DNPST inclusive of digital literacy and adaptive technology.

\section{Technology Perceptions and Attitudes}

The success of technology integration into teaching depends on teachers' attitudes, beliefs, and perceptions (Teo, 2008). Richardson (1996) states that,

"attitudes and beliefs are a subset of a group of constructs that name, define, and describe the structure and content of mental states that are thought to drive a person's actions" (p. 102).

Within the technology attitude and perception literature, some studies state that compared with other professions, teachers are the most hesitant users of technology in workplace (Paprzycki \& Vidakovic, 1994) in spite of many teachers' claims of positive perceptions in integrating technology into teaching. This variety of perceptions provide a potential fertile ground for great improvement especially with respect to technology use in classroom (Brown, 2017). These attitudes, beliefs and perceptions usually are connected to one's background and influence their actions. Richardson (1996) explained that 
attitudes and perceptions are reflected in people's actions and, as a result, teachers do not seem to reflect their true attitudes about integrating technology into teaching.

To understand teachers' perceptions about using technology in classrooms, it is very important to shed light on the factors that may affect using technology in classrooms. According to Teo (2008), teachers' attitudes and perceptions toward integrating technology into teaching are affected by some factors such as training (Tsitouridou \& Vryzas, 2003), knowledge of technology (Yuen, Law, \& Chan, 1999), usefulness, and technology confidence (Rovai \& Childress, 2002). In addition, Bai and Ertmer(2008) state that teachers' nontraditional teaching practices and beliefs influence teachers' motivation and attitudes about integrating technology into teaching. Teachers who adopt student-centered pedagogy are more likely to use technology in classroom than those teachers who adopt teacher-centered pedagogy. Since DNPSTs' attitudes and perceptions about using technology in classrooms are personal, it is a hard task to understand or to change (Instefjord, \& Munthe, 2017; Tondeur, van Braak, Ertmer, \& Ottenbreit-Leftwich, 2017). As new candidates enter teacher education programs, it is worthy to warrant an understanding of how their attitudes and perceptions influence learning new technologies such as COSOA, as well as the factors that affect DNPSTs' attitudes about using technology in classroom.

Specifically, pedagogical intention is defined as teachers' pedagogical beliefs and perceptions about teaching, learning and technology. Becker (1994) recommended the development of teachers who

"suggest a classroom environment in which technology is both prominent in the experience of students and employed in order that students grow intellectually and not merely develop isolated skills" ( $\mathrm{p}$. 294).

Teachers are embodied as a good exemplar of integrating technology into teaching. As a result, teachers' perceptions about when, how, and what ways to integrate technology into teaching are critical.

\section{Methodology}

This study investigates the effectiveness of instruction for a technology integration course which is prerequisite for entering the pre-service teacher preparation program at the college of education. In addition to evaluating student learning outcomes, this study addresses the classroom environment in providing pre-service teachers with a variety of alternate models of technology tools to enhance their current teaching repertoire. Data from this study will provide a path for curricular updates and improvement for technology integration courses implemented in pre-service teacher education programs. The overarching research question for this study is "After exposure to technology integration coursework, how will digital native pre-service teachers' perceptions 
change about using commercial and open source technology tools for future praxis?"

\section{Apparatus and Materials}

The Likert scale questionnaire which was given in the previous study was used to collect the data (Authors, 2016). Six (6) levels on the Likert scale were used for the study and are appropriate, including the deletion of the neutral response (Clason \& Dormody, 1994). The answers were reported numerically from 1-6 and each number was a placeholder for representing an individual group of participants such as strongly disagree, moderately disagree, slightly disagree, slightly agree, moderately agree, strongly agree respectively.

\section{Procedures and Results}

This study was conducted at a border city university where a population of pre-service teachers share different backgrounds, cultures and values. This study utilized a pre-post test design and participation was voluntary, based on random selection. A minor difference occurred in number of participants from pre-test $(\mathrm{N} 1=61)$ to post-test $(\mathrm{N} 2=60)$. The participants were enrolled in a technology integration course in college of education at South Mountain University.

As shown on the Table 1, the majority of the participants were female (pre-test: $82.25 \%$; Post-test: $85 \%$ ). As expected, the majority of participants were in the age group of 18-23 (pre-test: $77.05 \%$; post-test: $76.67 \%$ ) compared to the other three age groups which were below 18, 23-28, 28-33, and above 33. In sample group it should be noted that most of the participants were in elementary education programs (pre-test: $45 \%$; post-test: $44.83 \%$ ), and, $91.67 \%$ of participants indicated that they have a personal computer that they can access. $86.89 \%$ of pre-test and $93.34 \%$ of post-test takers mentioned that their computer proficiency was average or above average. Vast majority of the participants claimed to have their own personal computers (pre-test: $95 \%$; post-test:92\%).

Table 1: Descriptive information of the participants

\begin{tabular}{|l|l|c|c|c|c|}
\hline \multirow{2}{*}{} & \multirow{2}{*}{} & \multicolumn{2}{|c|}{ Pre-test } & \multicolumn{2}{c|}{ Post-test } \\
\cline { 2 - 6 } & $\begin{array}{c}\text { Number of } \\
\text { Students }\end{array}$ & $\begin{array}{c}\text { Percentage in } \\
\text { the sample }\end{array}$ & $\begin{array}{c}\text { Number of } \\
\text { Students }\end{array}$ & $\begin{array}{c}\text { Percentage in } \\
\text { the sample }\end{array}$ \\
\hline Gender & Female & 52 & 85.25 & 51 & 85.00 \\
\hline & Male & 9 & 14.75 & 8 & 13.33 \\
\cline { 2 - 6 } & $\begin{array}{l}\text { Prefer not to } \\
\text { respond }\end{array}$ & 0 & - & 1 & 1.67 \\
\hline Age group & $18-23$ & 47 & 77.05 & 46 & 76.67 \\
\hline
\end{tabular}




\begin{tabular}{|c|c|c|c|c|c|}
\hline & $23-28$ & 10 & 16.39 & 9 & 15.00 \\
\hline & $28-33$ & 3 & 4.92 & 4 & 6.67 \\
\hline & Above 33 & 1 & 1.64 & 1 & 1.67 \\
\hline \multirow[t]{3}{*}{ Major } & Elementary & 38 & 62.3 & 38 & 63.33 \\
\hline & Middle & 10 & 16.39 & 10 & 16.67 \\
\hline & High & 13 & 21.31 & 12 & 20 \\
\hline \multirow[t]{3}{*}{$\begin{array}{l}\text { Computer } \\
\text { Access }\end{array}$} & $\begin{array}{l}\text { No access at } \\
\text { home }\end{array}$ & 1 & 1.64 & 1 & 1.67 \\
\hline & $\begin{array}{l}\text { Have a personal } \\
\text { computer }\end{array}$ & 58 & 95.08 & 55 & 91.67 \\
\hline & $\begin{array}{l}\text { Have shared } \\
\text { access }\end{array}$ & 2 & 3.28 & 4 & 6.67 \\
\hline \multirow{5}{*}{$\begin{array}{l}\text { Computer } \\
\text { proficiency }\end{array}$} & Average & 30 & 49.18 & 28 & 46.67 \\
\hline & Fair & 7 & 11.48 & 4 & 6.67 \\
\hline & High & 16 & 26.23 & 22 & 36.67 \\
\hline & Low & 1 & 1.64 & 0 & - \\
\hline & Very high & 7 & 11.48 & 6 & 10 \\
\hline
\end{tabular}

Non-parametric tests are type of statistical tests that do not require the data to follow a particular distribution, typically used when assumptions of a parametric test are not met or when the data do not fit the level of measurement required by a parametric test. The Wilcoxon rank sum-test is a non-parametric test used to assess for significant differences when assumptions of T-Test was not met (Ott \& Longnecker, 2015). It is the non-parametric equivalent of the independent samples T-Test. The Wilcoxon rank sum-test uses the mean ranks of scores in each group to compute the P-value. A significant result for this test suggests that the two groups have reliably different scores on the dependent variable so that the null hypothesis can be rejected. The Wilcoxon rank sum test assumes that the observations are independent of each other and that the dependent variable has a scale of ordinal level of measurement. In this study pre-test results compared to post-test results to find out if there was a significant change in student perceptions after taking the course.

The question posed to the participants was if they were interested in using technology tools in their future teaching practices. When analysis was completed the p-value for Wilcoxon rank sum test was not significant to claim that taking the course affected the outcomes: $z=0.46, p=0.65(\alpha=0.05)$. The mean 
rank for Pre-test was 59.11 and mean rank for post-test was 61.94 as shown on the Figure 1 . These results suggest that the distribution of analysis for post-test is not significantly different from the distribution of pre-test. The participants did not show any significant thought change about using technology in classroom after taking the course.

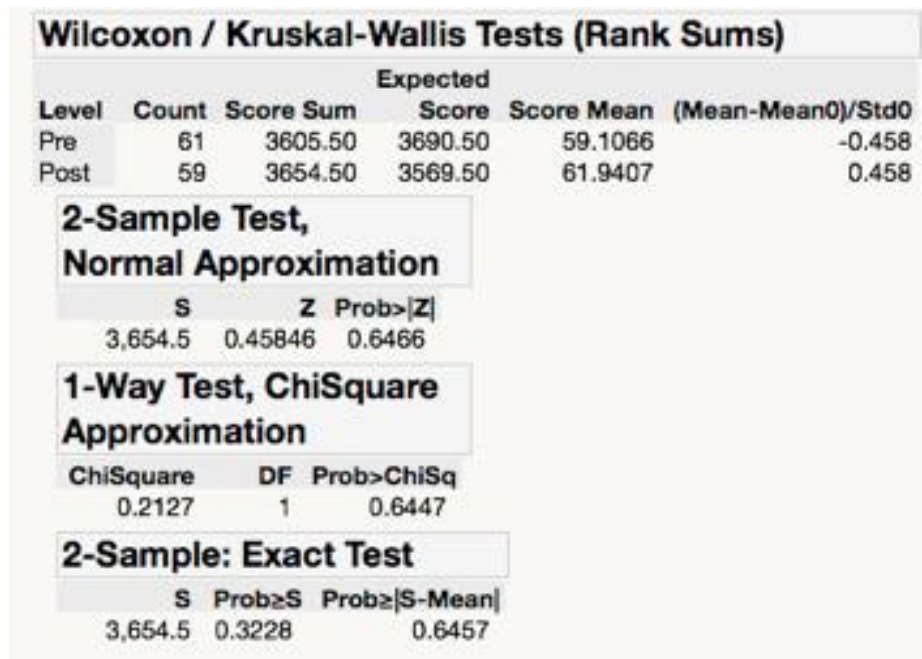

Figure 1: Wilcoxon rank sum test results

\section{Discussion}

The Wilcoxon rank sum tests show that based upon pre and post-tests, there was no significant change in perceptions of pre-service teachers in their willingness to leave their comfort zone and incorporate innovative tools into their praxis after participation in the technology integration course. DNPSTs' unchanging perspectives indicate their complacency in their ability to manage technology; they do not feel technology is an epic advancement in classroom because they are from a generation that was unaffected by the paradigm of computer-based classroom integration. Thus, having brought up in the culture, there is an intrinsic expectation that one possesses the capacity for managing technology. The classroom space is only an entity; whereas technological skills abound limitlessly.

The results of this study point to a quagmire amongst technology instructors in what constitutes as innovative technology considerable for DNPSTs to incorporate into a classroom setting. Students enrolled in this course have no prior classroom teaching experience and with this in mind, are provided instructional models that are of sterling worth. We can surmise that technology complacency exists; therefore, improvements to this technology methods course include contextualization of technology resources. Connecting DNPSTs with experiences to enhance their technological stockpile remains a challenge in a dynamic classroom climate.

The results of this study reveal that the attitudes of the participants reflected self-assuredness in technological finesse and pedagogical skills suitable for 
classroom instruction. Therefore, according to the participants, enrollment in future studies within this area was a moot point.

In this case, DNPSTs feel traditional instructional tools that do not rely on technology are still as effective as those inclusive of technology. Pre-service teachers were confident in their abilities towards effectiveness in student motivation sans technology. This lack of change in attitude reflects classroom practices that don't rely heavily on technology as a method solely for student achievement purposes.

According to the findings of this study, the proclivity of technology integration for the purpose of motivation was not demonstrated in the attitudes of pre-service teachers. One possible explanation is that the attitude held by DNPST is one which views technology as an item that is purposeful yet quotidian. Since technology is mainstay, it is not seen as an enterprise worth cultivating or improving upon. In this case, a recommendation should be made to examine course materials and course objectives. Student learning outcomes were not met as the learning goals for the course had projected. This study lends the authors to believe that DNPST need further engagement in actual classrooms. Specifically, K-12 classrooms where technologically supported teaching and learning exists. This exposure and participation will provide DNPST with opportunities to explore their practices of using and viewing technology as a pedagogical tool; therefore, challenging their current mindset. As pre-service teachers make connections with students and become better acquainted with curriculum, attitudes towards technological advancement will become a necessity for successful learning environments.

\section{References}

Adams Becker, S., Cummins, M., Davis, A., Freeman, A., Hall Giesinger, C., and Ananthanarayanan, V. (2017). NMC Horizon Report: 2017 Higher Education Edition. Austin, Texas: The New Media Consortium.

Ajzen, I., \& Fishbein, M. (1980). Understanding attitudes and predicting social behaviour. Englewood Cliffs, NJ: Prentice-Hall

Anderson, S. E., \& Maninger, R. M. (2007). Preservice teachers' abilities, beliefs, and intention regarding technology integration. Journal of Educational Computing Research, 37(2), 151-172. doi: https:/ / doi.org/10.2190/H1M8-562W-18J1-634P

Asing-Cashman, J. G., Gurung, B., Limbu, Y. B., \& Rutledge, D. (2014). Free and Open Source Tools (FOSTs): An Empirical Investigation of Pre-Service Teachers' Competencies, Attitudes, and Pedagogical Intentions. International Journal of Teaching and Learning in Higher Education, 26(1), 66-77.

Bai, H., \& Ertmer, P. (2008). Teacher educators' beliefs and technology uses as predictors of preservice teachers' beliefs and technology attitudes. Journal of Technology and Teacher Education, 16(1), 93-112.

Baylor, A. L., \& Ritchie, D. (2002). What factors facilitate teacher skill, teacher morale, and perceived student learning in technology-using classrooms?. Computers $\mathcal{E}$ Education, 39(4), 395-414. 
Becker, H. J. (1994). How exemplary computer-using teachers differ from other teachers: Implications for realizing the potential of computers in schools. Journal of Research on Computing in Education, 26, 291-321.

Brown, J. P. (2017). Teachers' perspectives of changes in their practice during a technology in mathematics education research project. Teaching and Teacher Education, 64, 52-65.

Bullen, M., \& Morgan, T. (2016). Digital learners not digital natives. La Cuestión Universitaria, (7), 60-68.

Choy, D., Wong, A. F. L., \& Gao, P. (2009). Student teachers' intentions and actions on integrating technology into their classrooms during student teaching: A Singapore study. Journal of Research on Technology in Education,42(2), 175-195. doi:10.1080/15391523.2009.10782546

Clason, D. L., \& Dormody, T. J. (1994). Analyzing data measured by individual Likerttype items. Journal of Agricultural Education, 35(4), 31-35.

Corkett, J. K., \& Benevides, T. (2015). Preservice teachers' perceptions of technology and multiliteracy within the inclusive classroom. International Journal of Psychology and Educational Studies, 2(2), 35-46.

Davis, F. D. (1989). Perceived usefulness, perceived ease of use, and user acceptance of information technology. MIS quarterly, 319-340.

Drumea, A. (2012). Education in Development of Electronic Modules using Free and Open Source Software tools. Magazine of Hydraulics, Pneumatics, Tribology, Ecology, Sensorics, Mechatronics, 3(4), 54-60.

Dwyer, D. (1996). A response to Douglas Noble: We're in this together. Educational Leadership,54(3), 24-25.

Goldberg, A., Russell, M., \& Cook, A. (2003). The effect of computers on student writing: A meta-analysis of studies from 1992 to 2002. Journal of Technology, Learning and Assessment, 2(1), 3-51. http://ejournals.bc.edu/ojs/index.php/jtla/article/view/1661/1503

Greenhow, C., Robelia, B., \& Hughes, J. E. (2009). Learning, Teaching, and Scholarship in a Digital Age: Web 2.0 and Classroom Research: What Path Should We Take Now? Educational Researcher, 38(4), 246-259.

Homo Zappiens. (2017). Nature,547(7664), 380. doi:10.1038/547380a

Howe, N., \& Strauss, W. (2000). Millennials rising: The next great generation. Vintage.

Instefjord, E. J., \& Munthe, E. (2017). Educating digitally competent teachers: A study of integration of professional digital competence in teacher education. Teaching and Teacher Education, 67, 37-45.

International Society for Technology in Education [ISTE]. (2008). ISTE standards: Teachers. Retrieved from http://www.iste.org/docs/pdfs/20-14_ISTE_StandardsT_PDF.pdf

Kirschner, P. A., \& De Bruyckere, P. (2017). The myths of the digital native and the multitasker. Teaching and Teacher Education, 67, 135-142. doi:https://doi.org/10.1016/j.tate.2017.06.001

Lambert, J., \& Cuper, P. (2008). Multimedia technologies and familiar spaces: 21st century teaching for 21st century learners. Contemporary Issues in technology and teacher education, 8(3), 264-276.

Levin, D., \& Arafeh, S. (2002). The digital disconnect: The widening gap between Internetsavvy students and their schools. Washington, DC: Pew Internet \& American Life Project. Retrieved from http://eric.ed.gov/?id=ED471133

Lim, W. M. (2018). Dialectic Antidotes to Critics of the Technology Acceptance Model: Conceptual, Methodological, and Replication Treatments for Behavioural Modelling in Technology-Mediated Environments. Australasian Journal of Information Systems. 
Margaryan, A., Littlejohn, A., \& Vojt, G. (2011). Are digital natives a myth or reality? University students' use of digital technologies. Computers and Education, 56, 429440. doi:http://dx.doi.org/10.1016/j.compedu.2010.09.004.

Marri, A. R. (2005). Educational technology as a tool for multicultural democratic education: The case of one US history teacher in an under resourced high school. Contemporary Issues in Technology and Teacher Education, 4(4), 395-409.

Mouza, C., \& Karchmer-Klein, R. (2013). Promoting and assessing pre-service teachers technological pedagogical content knowledge (TPACK) in the context of case development. Journal of Educational Computing Research, 48(2), 127-152.

National Council for Accreditation of Teacher Education. (2007). Professional standards for the accreditation of schools, colleges, and departments of education. Washington.

Office of Technology Assessment (OTA). (1995). Teachers and technology: making the connection.Washington, DC: US Government Printing Office.

Ott, R. L., \& Longnecker, M. T. (2015). An introduction to statistical methods and data analysis. Nelson Education.

Paprzycki, M., \& Vidakovic, D. (1994). Prospective teachers' attitudes toward computers. In D. Willis, B. Robin, \& J Willis (Eds.), Technology and teacher education annual1994(pp. 74-76). Charlottesville, VA: Association for the Advancement of Computing in Education.

Prensky, M. (2001). Digital natives, digital immigrants part 1. On the Horizon, 9(5), 1-6.

Prensky, M. (2005). Listen to the natives. Educational Leadership, 63(4), 8-13.

Prensky, M. (2009). H. sapiens digital: From digital immigrants and digital natives to digital wisdom. Innovate: journal of online education, 5(3), 1.

Richardson, V. (1996). The role of attitudes and beliefs in learning to teach. In J. Sikula (Ed.), Handbook of research in teacher education(2nd ed., pp. 102- 119). New York, NY: Macmillan.

Rovai, A. P. \& Childress, M. D. (2002). Explaining and predicting resistance to computer anxiety reduction among teacher education students. Journal of Research on Technology in Education,35(2), 226-235.

Rutledge, D., Ozer, M., Altamirano, A., Mansour, T., \& Latorre, J. (2016, March). A Replication Study of Pre-Service Teachers' Perceptions in Using Free and Open Source Tools. In Society for Information Technology \& Teacher Education International Conference (pp. 2294-2300). Association for the Advancement of Computing in Education (AACE).

Tapscott, D. (2009). Grown Up Digital: How The Net Generation is Changing Your World. Toronto: McGraw-Hill.

Teo, T., Lee, C. B., Chai, C. S., \& Wong, S. L. (2009). Assessing the intention to use technology among pre-service teachers in Singapore and Malaysia: A multigroup invariance analysis of the technology acceptance model. Computers \& Education, 53(3), 1000-1009. doi:10.1016/j.compedu.2009.05.017

Teo, T. (2008). Pre-service teachers' attitudes towards computer use: A Singapore survey. Australasian Journal of Educational Technology, 24(4), 413-424.

Teo, T. (2009) Modelling technology acceptance in education: A study of pre-service teachers. Computers \& Education,52, 302-312. doi:10.1016/j.compedu.2008.08.006

Tondeur, J., van Braak, J., Ertmer, P. A., \& Ottenbreit-Leftwich, A. (2017). Understanding the relationship between teachers' pedagogical beliefs and technology use in education: a systematic review of qualitative evidence. Educational Technology Research and Development, 65(3), 555-575.

Tsitouridou, M. \& Vryzas, K. (2003). Early childhood teachers' attitudes towards computer and information technology: The case of Greece. Information Technology in Childhood Education Annual,1, 187-207. 
Uerz, D., Volman, M., \& Kral, M. (2018). Teacher educators' competences in fostering student teachers' proficiency in teaching and learning with technology: An overview of relevant research literature. Teaching and Teacher Education, 70, 12-23.

Venkatesh, V., \& Davis, F. D. (2000). A theoretical extension of the technology acceptance model: Four longitudinal field studies. Management science, 46(2), 186-204.

Yuen, H. K., Law, N. \& Chan, H. (1999). Improving IT training for serving teachers through evaluation. In G. Cumming, T. Okamoto \& L. Gomez (Eds), Advanced research in computers and communications in education, Amsterdam: IOS Press, Vol. 2, pp.441-448.

Zhao, Y., Pugh, K., Sheldon, S., \& Byers, J. L. (2002). Conditions for classroom technology innovations. Teachers College Record, 104(3), 482-515.doi:10.1111/1467-9620.00170 